\title{
Correction: Value of small sample sizes in rapid- cycle quality improvement projects
}

Etchells E, Ho M, Shojania KG. Value of small sample sizes in rapid-cycle quality improvement projects. BMJ Qual Safe 2016;25:202-6.

The article has been corrected since it was published online. The authors want to alert readers to the following error identified in the published version. The error is in the last paragraph of the section "Small samples can make 'rapid improvement' Rapid", wherein the minimum sample size has been considered as six instead of eight.

For this first (convenience) sample of 10 volunteer users, $5 / 10(50 \%)$ completed the form without any input or instructions. The other five became frustrated and gave up. Table 1 tells you that, with an observed success rate of 50\% and a desired target of $90 \%$, any audit with a sample of six or more allows you to confidently reject the null hypothesis that your form is working at a $90 \%$ success rate.

(C) Author(s) (or their employer(s)) 2020. No commercial re-use. See rights and permissions. Published by BMJ.

BMJ Qual Saf 2020;29:e1. doi:10.1136/bmjqs-2015-005094corr 1

A Check for updates 